\title{
Geology and controls on mineralisation in the Eastern Goldfields region, Yilgarn Craton, Western Australia
}

\footnotetext{
${ }^{1}$ Geological Survey of Western Australia, 100 Plain St, East Perth, WA 6004, Australia. E-mail: stephen.wyche@dmp.wa.gov.au

${ }^{2}$ Centre for Exploration Targeting and Australian Research Council Center of Excellence for Core to Crust Fluid Systems, School of Earth and Environment, University of Western Australia, Crawley, WA 6009, Australia.E-mail:marco.fiorentini@uwa.edu.au; john.miller@uwa.edu.au; campbell.mccuaig@uwa.edu.au
}

The Yilgarn Craton in Western Australia contains evidence of the oldest crust on Earth. Greenstone successions developed after c. 3000 Ma show a complex history of juvenile crust generation and crustal reworking. There are at least three periods of greenstonerelated magmatism in the Yilgarn Craton. The earliest recognised greenstone development consists of volcanic and sedimentary successions deposited between c. 30002900 Ma. A mantle plume at c. 2800 Ma produced large mafic-ultramafic igneous complexes and probably initiated rifting on the eastern side of the craton and incipient rifting in the NW. A second major plume, at c. $2700 \mathrm{Ma}$, was focussed along the rupture created by the c. 2800 Ma event and may have been associated with the re-accretion of lithospheric blocks created by the earlier event. Komatiites generated by the c. $2700 \mathrm{Ma}$ plume contain world-class Ni deposits, and structures developed subsequent to the peak of plume activity host world-class Au deposits. Recent studies of Ni and Au deposits in the Eastern Goldfields Superterrane have shown how features ranging in scale from the lithosphere to regional structural and stratigraphic controls to local volcanological and sedimentological variations can affect the size and distribution of deposits. This understanding is now being applied in exploration targeting.

\section{Introduction}

The Paleo-Neoarchean Yilgarn Craton in Western Australia (Figure 1) is a highly mineralised granite-greenstone terrain with world-class deposits of $\mathrm{Au}$ and $\mathrm{Ni}$, and significant iron and volcanichosted massive sulphide (VHMS) base-metal deposits. Economic Fe deposits are confined to the western part of the craton.

Over the past 15 years, the acquisition of large datasets and major advances in the understanding of the geological evolution of the
Yilgarn Craton at all scales have encouraged the application of the holistic mineral systems approach to mineral exploration as a tool for developing targeting criteria, particularly for $\mathrm{Ni}$ and $\mathrm{Au}$ (McCuaig et al., 2010). In this review, examples from the Kambalda district in the Eastern Goldfields region illustrate how the size, distribution and concentration of $\mathrm{Au}$ and $\mathrm{Ni}$ deposits are controlled by factors from the craton to the regional scale, down to the deposit cluster and individual deposit scale. While there has been little recent, regionalscale work on Yilgarn VHMS deposits, comparison with similar terrains in Canada suggests that the fundamental controls on $\mathrm{Ni}$ mineralisation also influence the distribution and endowment of VHMS mineralisation (Huston et al., 2005).

\section{Yilgarn Craton}

Cassidy et al. (2006) divided the Yilgarn Craton into terranes defined on the basis of distinct sedimentary and magmatic associations, geochemistry and ages of volcanism. The Narryer and South West terranes in the west are dominated by granite and granitic gneiss with minor supracrustal greenstone inliers, whereas the Youanmi Terrane and the Eastern Goldfields Superterrane contain substantial greenstone belts separated by granite and granitic gneiss. Subsequent revision has further subdivided the Eastern Goldfields Superterrane into the Kalgoorlie, Kurnalpi, Burtville and Yamarna terranes (Figure 1; Pawley et al., 2012).

The Ida Fault (Figure 1), which marks the boundary between the western Yilgarn Craton and the Eastern Goldfields Superterrane, is a major structure that extends to the base of the crust (Drummond et al., 2000). Various geophysical techniques, including deep-crustal seismic (Drummond et al., 2000; Goleby et al., 2003), seismic receiver-function analysis (Reading et al., 2007), and magnetotelluric surveys (Dentith et al., 2012), show the Yilgarn crust to be $32-46 \mathrm{~km}$ thick, with the shallowest Moho beneath the Youanmi Terrane. The crust is thicker in the SW, and thickest in the eastern part of the Eastern Goldfields Superterrane. Seismic and gravity data suggest that the greenstones are 2-7 km thick (Swager et al., 1997).

Isotopic data, including Sm-Nd (Figure 2; Champion and Cassidy, 2007) and Lu-Hf (Mole et al., 2010; Wyche et al., 2012) data, show that the terrane subdivisions of the Yilgarn Craton reflect regions with distinctive crustal histories. The Narryer Terrane, which contains both the oldest detrital zircons yet found on Earth (back to c. 4400 Ma; Wilde et al., 2001) and the oldest rocks in Australia (back to c. 


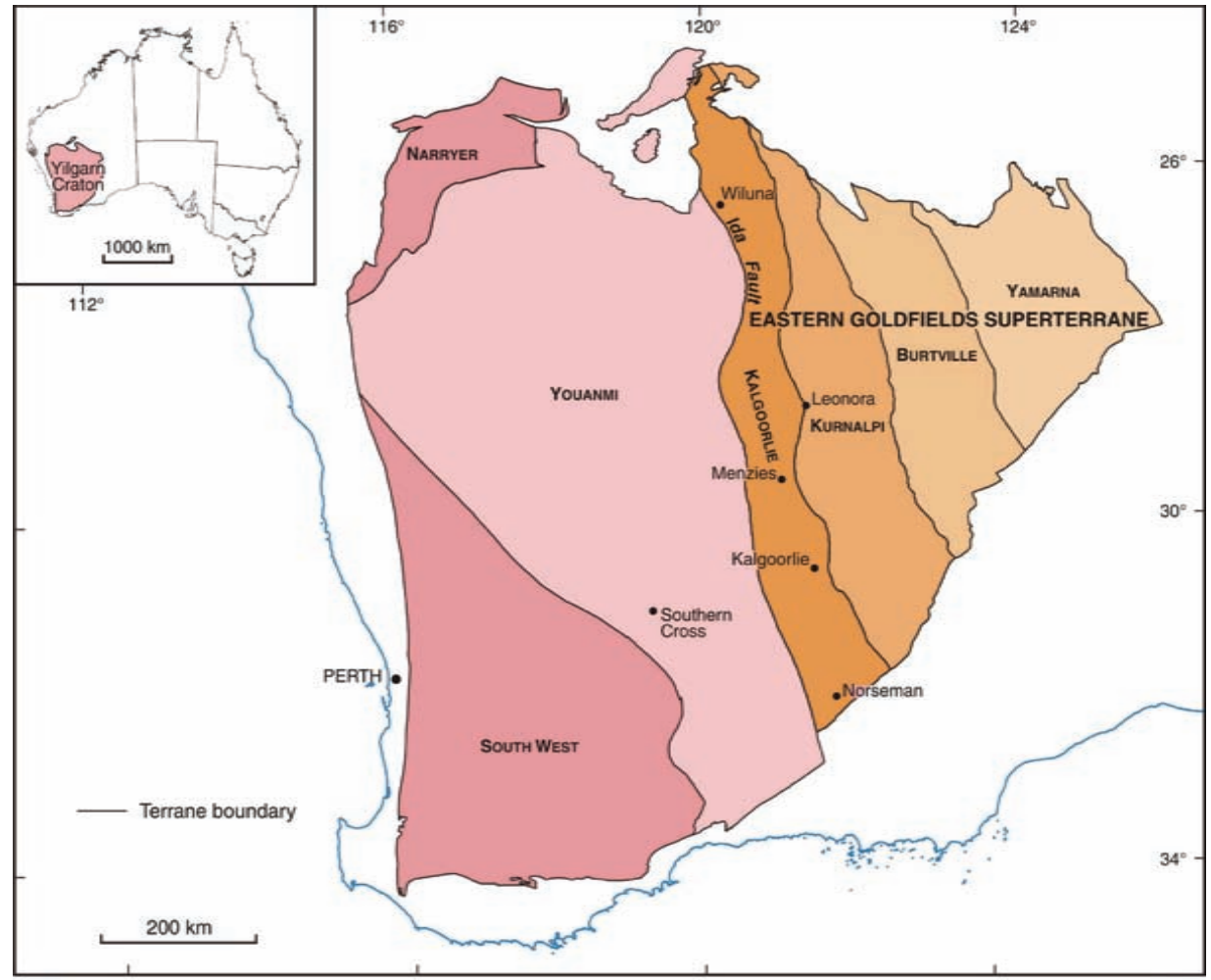

Figure 1 Subdivision of the Yilgarn Craton (modified from Pawley et al., 2012).

Except for rare greenstones in the South West Terrane (Allibone et al., 1998), after c. $2715 \mathrm{Ma}$, volcanic activity and greenstone development in the Yilgarn Craton was restricted to the Eastern Goldfields Superterrane. Andesitedominated calc-alkaline volcanism in the eastern Kurnalpi Terrane (Figures 1 and 3; Barley et al., 2008) and dacitic volcanism in the northern Kalgoorlie Terrane (Rosengren et al., 2005) was prevalent between c. 2715-2705 Ma (Fiorentini et al., 2005; Kositcin et al., 2008). Barley et al. (2008) interpreted the andesitedominated successions as oceanic intra-arc volcanic centres.

In the Eastern Goldfields Superterrane, a second major plume event (Campbell and Hill, 1988) produced voluminous komatiites which occur as both high-level intrusions and flows (Trofimovs et al., 2004; Fiorentini et al., 2005, 2010). They are preserved in a distinct $\mathrm{N}-\mathrm{NW}$-trending belt, $600 \times 100 \mathrm{~km}$, between Norseman and Wiluna (Figure 1). The mafic-ultramafic succession also contains tholeiitic and komatiitic basalts (Lesher, 1983; Squire et

3730 Ma; Kinny et al., 1988), shows abundant evidence of very old model ages. The Youanmi Terrane has a more mixed history, whereas the Eastern Goldfields Superterrane is distinctly more juvenile than the terranes to the west.

\section{Yilgarn granite-greenstones}

The supracrustal rock record in the Yilgarn Craton dates back to at least c. $3080 \mathrm{Ma}$ in the Youanmi Terrane in the west (Wang et al., 1998; Yeats et al., 1996; Rasmussen et al., 2010; Van Kranendonk et al., 2012) and c. $2960 \mathrm{Ma}$ in the Burtville Terrane in the NE (Pawley et al., 2012). However, greenstone successions across the Yilgarn Craton are dominated by rocks that formed after c. 2820 Ma.

In the central Youanmi Terrane, a cycle of mafic-ultramafic-felsic volcanism between c. $2820-2735 \mathrm{Ma}$ is likely due to a major plume that produced large mafic-ultramafic layered intrusions between $\mathrm{c}$. 2820-2800 Ma (Ivanic et al., 2010), coincident with similar, but less voluminous, magmatism in the eastern part of the craton (Wyche et al., 2012). This event may have resulted in partial break-up of the early Yilgarn Craton with rifting in the east (Czarnota et al., 2010) and incipient rifting marked by younger $\mathrm{Nd}$ model ages and the layered intrusions in the Youanmi Terrane (Ivanic et al., 2010). A protracted period of mafic - felsic volcanism and associated sedimentation continued from c. 2800-2735 Ma. Calc-alkaline volcanism was dominant after c. $2760 \mathrm{Ma}$, and broadly coincided with a period of mafic tonalite-trondhjemite-granodiorite (TTG) and enriched highfield-strength element (HFSE) granite magmatism (Cassidy et al., 2002; Van Kranendonk et al., 2012).

The last recognised regional greenstone-forming event in the Youanmi Terrane was a mafic to felsic volcanic cycle between c. 2740$2725 \mathrm{Ma}$ (Van Kranendonk et al., 2012), which was contemporaneous with high-Ca TTG granite magmatism (Cassidy et al., 2002). al., 1998; Said and Kerrich, 2009). It is well constrained between c. 2710-2692 Ma (Kositcin et al., 2008) and partly overlaps in age with the andesite-dominated calc-alkaline volcanism. The NorsemanWiluna komatiites, which host major Ni deposits, are not only younger than ultramafic rocks in the Youanmi Terrane, but also differ in chemical character. Komatiites of the Youanmi Terrane include Aldepleted, and Al-undepleted and Ti-enriched varieties, whereas those in the Norseman-Wiluna belt are Al-undepleted (Barnes et al., 2007). Abundant SHRIMP geochronological data on greenstones from throughout the Eastern Goldfields Superterrane (Geological Survey of Western Australia, 2011) suggest that thinner and more sparsely distributed komatiite units east of the Norseman-Wiluna belt (e.g., E and SE of Leonora; Figure 3) are mainly the same age as the more voluminous material within the main belt and may represent thin flows or channel deposits which have travelled farther as result of paleotopography.

Between c. 2692-2680 Ma, volcanic centres in the western part of the Kurnalpi Terrane produced bimodal (basalt-rhyolite) volcanic and associated intrusive and sedimentary rocks (Figure 3), coinciding with the main period of high-HFSE granite magmatism (Cassidy et al., 2002). Barley et al. (2008) interpreted these 'Gindalbie' successions as representing an arc-rift environment. Gindalbie-style volcanism, which locally hosts VHMS mineralisation, overlapped in age with, and was succeeded by, TTG volcanism and associated sedimentary rocks and mafic intrusions represented by the Black Flag Group in the Kalgoorlie Terrane (Figure 3). The deposition of the Black Flag Group between c. 2690-2660 Ma coincided with voluminous high-Ca TTG granite magmatism in the Eastern Goldfields Superterrane (Champion and Cassidy, 2007). Krapez and Hand (2008) interpreted the Black Flag Group (their 'Kalgoorlie Sequence') as representing a strike-slip intra-arc basin, whereas Squire et al. (2010) argued that they are the result of volcanism and sedimentation 


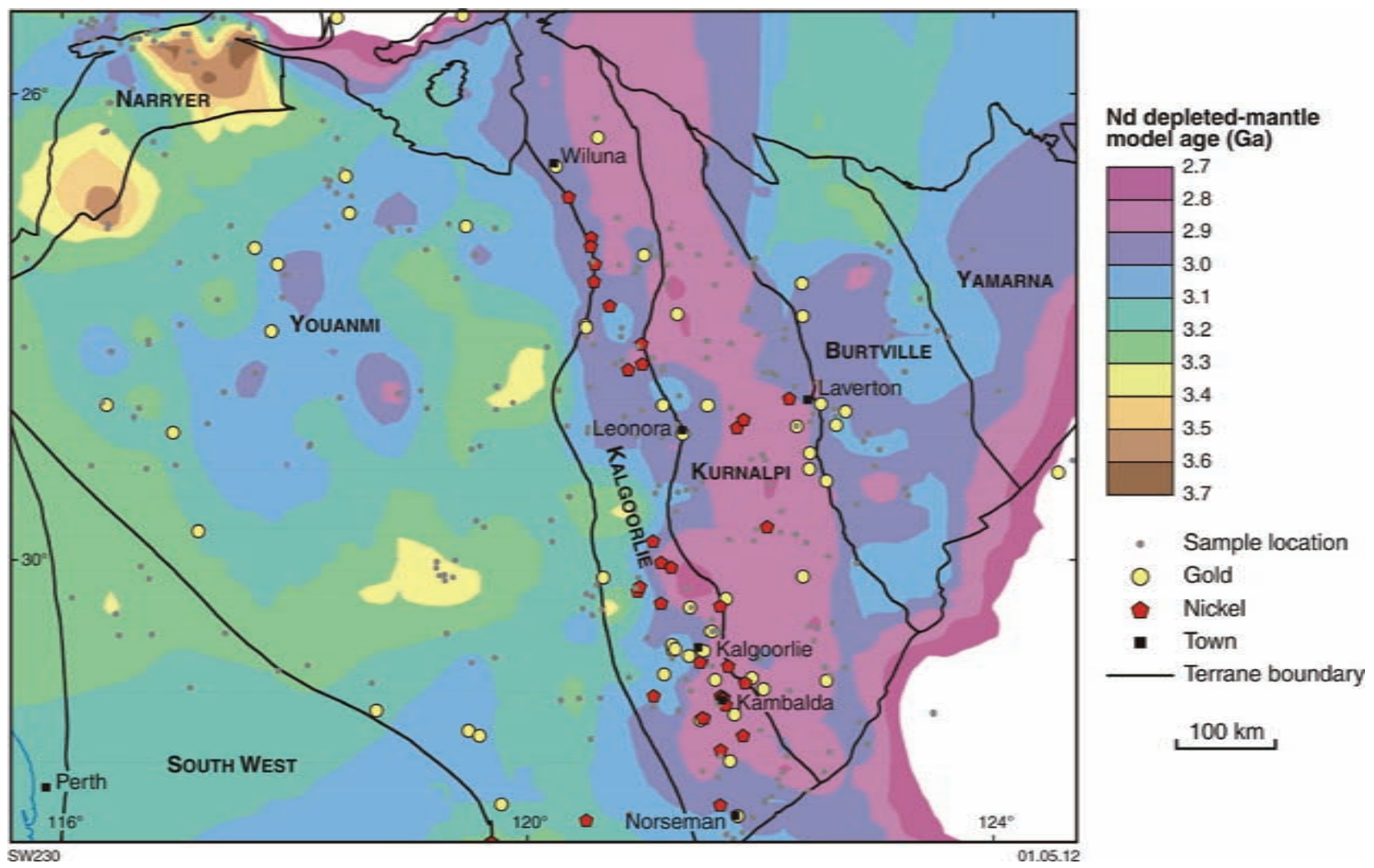

Figure 2 Nd depleted-mantle model age map for the Yilgarn Craton showing terrane subdivisions and locations of major Ni and Au deposits (modified from Champion and Cassidy, 2007).

associated with extensional deformation due to the emplacement of large granite batholiths. Felsic volcanic and associated plutonic rocks of this age have also been recorded in a poorly exposed bimodal greenstone succession in the Yamarna Terrane in the far E of the Eastern Goldfields Superterrane (Figure 1; Pawley et al., 2012).

The youngest supracrustal successions in the Yilgarn Craton are the so-called 'late basins', which rest unconformably on all earlier greenstones in the Eastern Goldfields Superterrane. Likely deposited in a very short time (c. $10 \mathrm{Myr}$ ) after c. $2665 \mathrm{Ma}$ (Squire et al., 2010), they preserve fluvial and deep-marine facies, which Krapez and Barley (2008) interpreted as having formed in a tectonic-escape corridor after arc closure. The late-basin sediments, which range from turbidites through to coarse, braided-stream sediments (Krapez et al., 2008), contain a range of detrital zircon ages and postdate the cessation of TTG granite magmatism. They contain material derived from both proximal and distal sources during ongoing extension and uplift (Squire et al., 2010).

Finally, the cessation of greenstone deposition was accompanied by craton-wide low-Ca granite magmatism (Cassidy et al., 2002). A distinctive belt of alkaline granites, emplaced at this time, appears to coincide with deeply penetrating crustal structures and is mainly restricted to the Kurnalpi Terrane (Smithies and Champion, 1999).

\section{Eastern Goldfields: stratigraphy and structure}

\section{Stratigraphy}

Poor exposure, deep weathering, lack of detailed geochronology, and structural and metamorphic overprints preclude description of detailed stratigraphy in many of the Yilgarn greenstones. West of the Ida Fault (Figure 1), only the NW part of the Youanmi Terrane has an established stratigraphy (Van Kranendonk et al., 2012). East of the Ida Fault, local stratigraphy has been established in some greenstone belts (Kositcin et al., 2008) but detailed regional stratigraphy has been described only for the southern part of the Kalgoorlie Terrane.

The southern Kalgoorlie Terrane (Figure 4; Woodall, 1965; Gresham and Loftus-Hills, 1981; Swager et al., 1995) comprises a lower mafic-ultramafic succession consisting of the Lunnon Basalt, Kambalda Komatiite (including the Silver Lake and Tripod Hill members), Devon Consols Basalt, Kapai Slate and Paringa Basalt. The mafic-ultramafic succession is unconformably overlain by the Black Flag Group, which comprises extensive volcaniclastic rocks, rhyolitic to dacitic volcanic rocks, intrusive mafic complexes and minor mafic volcanic rocks (Squire et al., 2010). The late-basin sediments are represented in this area by polymictic conglomerate of the Kurrawang Formation, which contains a variety of clasts, including banded-iron formation and granite that indicate a distal provenance, probably in the Youanmi Terrane (Krapez et al., 2008). In lessdeformed areas, many primary igneous features and textures are still visible despite locally complete replacement by alteration assemblages.

The abundant pillow lavas and hyaloclastites in basalts, the presence of marine sediments, and quench textures in komatiites and basalts indicate a submarine eruption of the mafic-ultramafic succession (Hill et al., 1995; Squire et al., 1998; Said and Kerrich, 2009). Squire et al. (1998) proposed that the Lunnon Basalt is either distal to a shield volcano, or represents a ponded lava field in an extensional basin distant from the eruptive centre. Similarly, Hill et al. (1995) suggested that the komatiite flows at Kambalda are distal deposits in contrast with the thick, cumulate dunite bodies to the $\mathrm{N}$ 


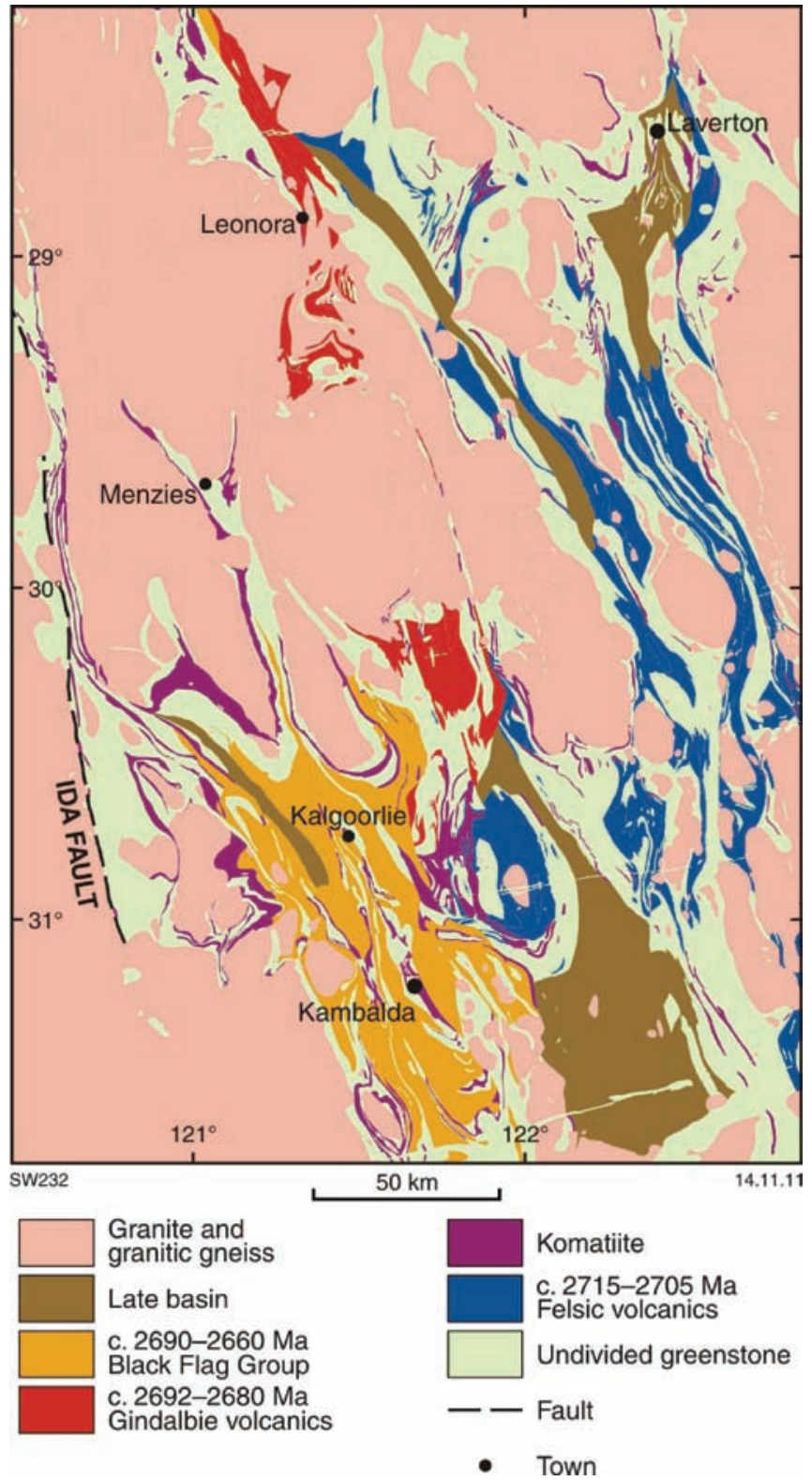

Figure 3 Distribution of main volcanic facies in the central part of the Eastern Goldfields Superterrane.

and NW of Kalgoorlie (Figure 3), which are proximal to the eruptive centre.

The nature of basement to the mafic-ultramafic succession in the Kalgoorlie region is unknown. Xenocrystic zircon age data (Compston et al., 1986) and trace-element and isotopic data suggest the maficultramafic succession may have been generated through varying degrees of crustal contamination (Arndt and Jenner, 1986) and mixing of a depleted mantle source with an enriched subcontinental lithospheric mantle (Said and Kerrich, 2009). Model age data based on Lu-Hf analyses on zircons have peaks after $3500 \mathrm{Ma}$, and mainly after $3100 \mathrm{Ma}$. This is significantly younger than the earliest model age recognised in the Youanmi Terrane (Wyche et al., 2012).

\section{Structure and metamorphism}

Building on the regional framework established by Swager (1997), Blewett et al. (2010a) produced a six-stage, integrated structural-event framework (Figure 5) for the Eastern Goldfields Superterrane to account for the documented magmatic, depositional, structural and metamorphic history (Czarnota et al., 2010). In this scheme, the period of greenstone deposition between c. 2715-2705 Ma, characterised by calc-alkaline and komatiite magmatism, was a time of dominantly extensional tectonics that marked the initiation of regional-scale granite doming.

The deposition of the Black Flag Group, between c. 2690$2660 \mathrm{Ma}$, was accompanied by the widespread emplacement of a high-Ca TTG granite suite. Granite doming was probably coeval with local contraction indicated by upright folding and dextral shearing at this time. The peak period of granite doming began during the last depositional phase of the Black Flag Group (Squire et al., 2010). Ongoing doming and extension produced the clastic latebasin sediments. After the cessation of high-Ca magmatism, low-Ca granite magmatism, which appears to be the result of melting of a mid-lower crustal source of TTG/high-Ca composition (Champion and Cassidy, 2007), was accompanied by a major contractional deformation, which produced both upright folds and regionalscale sinistral shearing which may have reactivated earlier structures. Subsequent, relatively minor, brittle contractional and extensional events affected the now rigid Yilgarn Craton (Czarnota et al., 2010).

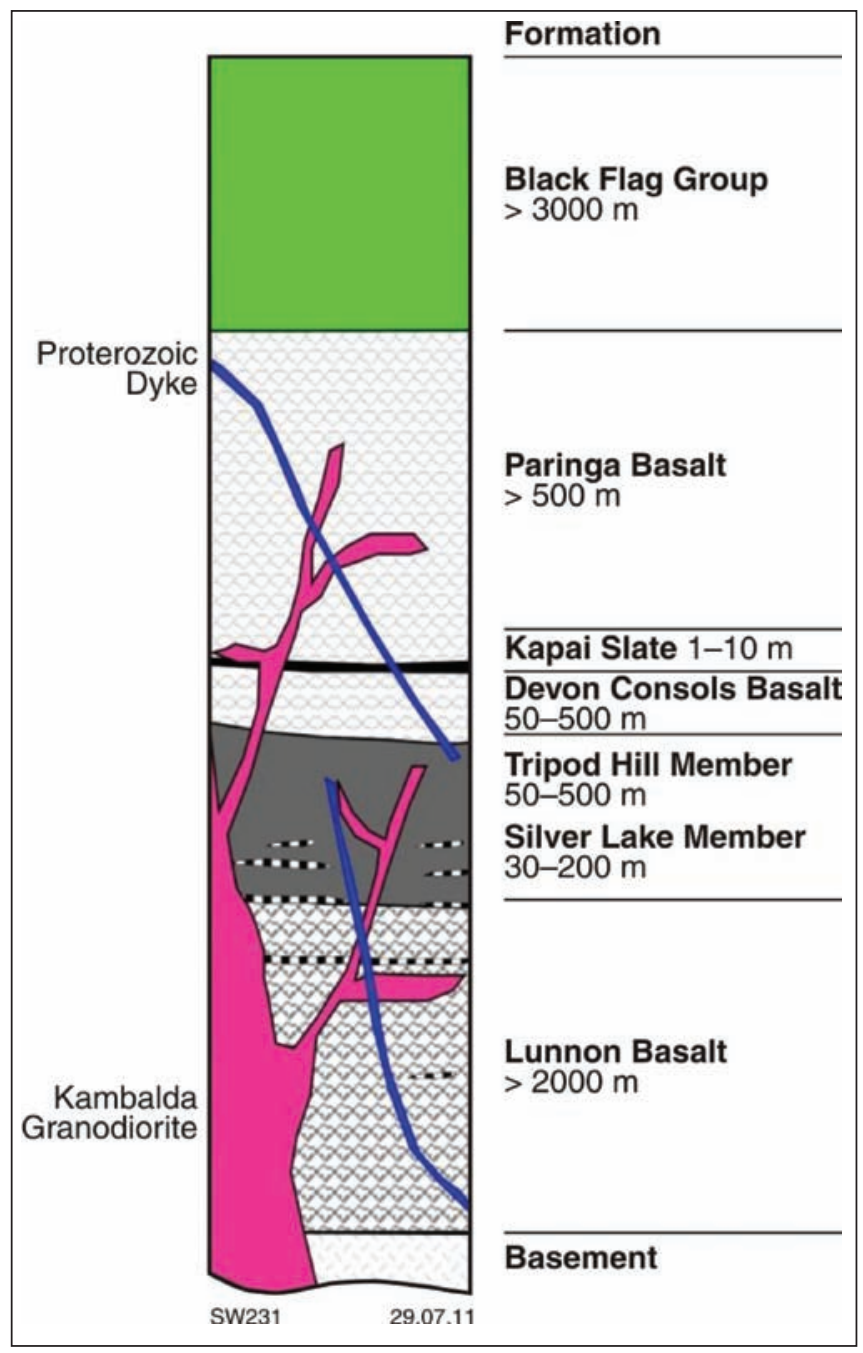

Figure 4 Kambalda stratigraphy (modified from Beresford et al., 2005). 


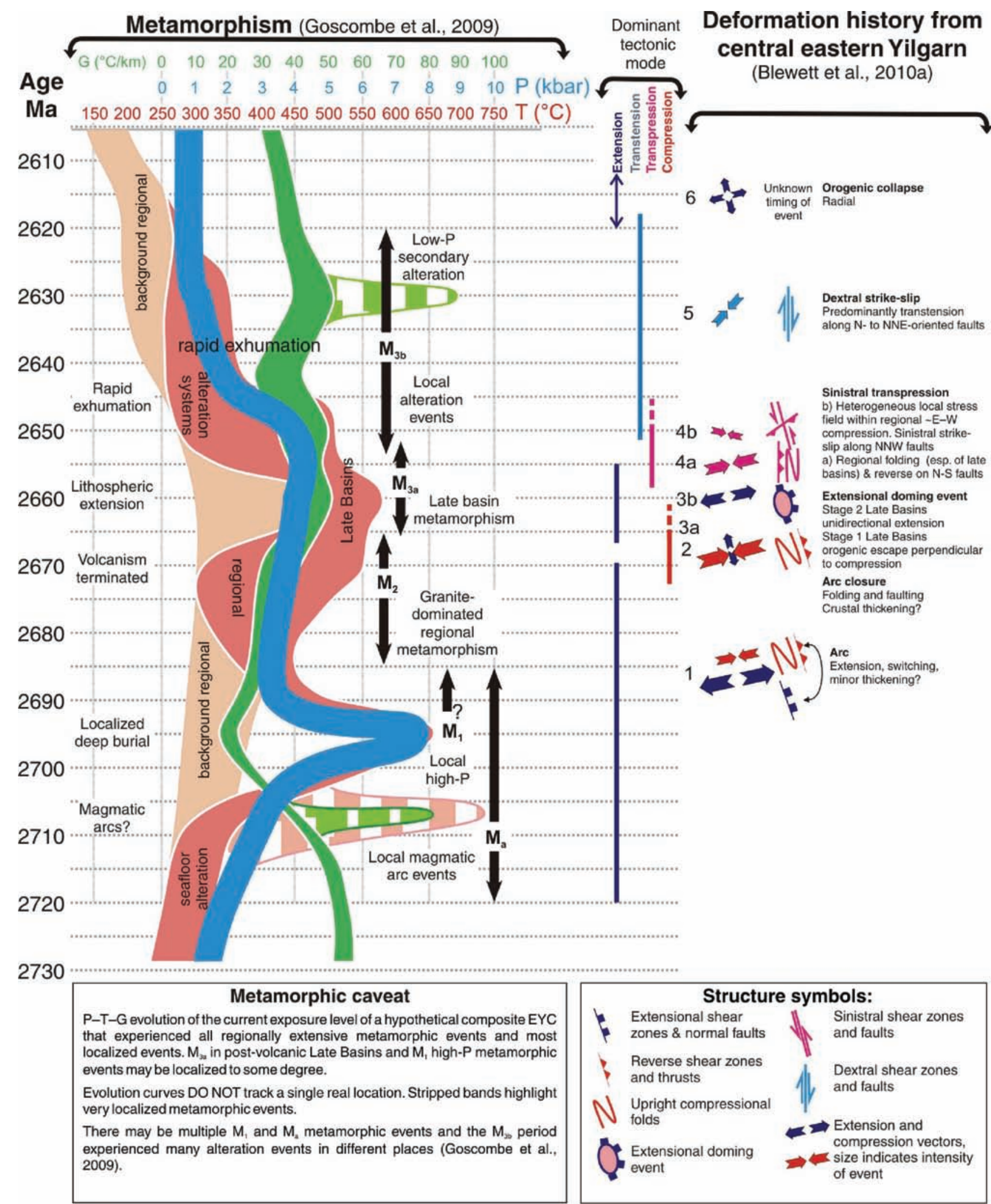

Figure 5 Metamorphic and structural history of the Eastern Goldfields Superterrane (modified from Czarnota et al., 2010).

Local evidence of early, low-pressure granulite-facies metamorphism, consistent with a high geothermal gradient (Figure 5; Goscombe et al., 2009), was contemporaneous with the eruption of the Norseman-Wiluna komatiites. Later medium-pressure metamorphism was most likely due to exhumation of deep-seated early structures around granite domes (Goscombe et al., 2009).
Subsequent periods of low pressure metamorphism, accompanied by moderate to high geothermal gradients, reflect exhumation during granite doming prior to and during late-basin development. Very low pressures and geothermal gradients mark the end of the period of granite doming and the initiation of widespread exhumation (Goscombe et al., 2009). 


\section{Eastern Goldfields: nickel and gold}

The stratigraphy, structure and metamorphic history of the southern Kalgoorlie Terrane remain the most comprehensively studied and documented part of the Yilgarn Craton. Consequently, this region provides the best insight into the multiscale factors that control the distribution of the world-class $\mathrm{Ni}$ and $\mathrm{Au}$ deposits of the eastern Yilgarn Craton.

\section{Nickel}

The most significant recent advances in understanding komatiite-hosted Ni-sulfide deposits in the Yilgarn Craton (Barnes, 2006) have been the recognition of: (1) different modes of emplacement, sulfur assimilation, and the difference in resultant mineralisation styles; and (2) large-scale architectural control on the location of Ni-sulfide deposit clusters. This new understanding has come from work on a number of major Ni deposits in the Eastern Goldfields such as Mount Keith (e.g., Fiorentini et al., 2007), Black Swan (e.g., Barnes, 2004) and Kambalda (e.g., Gresham and LoftusHills, 1981; Lesher, 1983). The Kambalda deposits were the first discovered and have the longest history of both exploitation and research. They provide a useful illustration of how factors at all scales affect the accumulation of major $\mathrm{Ni}$ deposits in this geological province.

Nickel-sulfide mineralisation was first discovered at Kambalda (Figure 3) in 1966, c. 70 years after the discovery of Au in the region. Mineralisation is hosted in the Kambalda dome, a doubly plunging anticline cored by granitic intrusions, which post-date the Ni-sulfide mineralisation. Mineralisation is primarily within the volcanic stratigraphy exposed along the flanks of the intrusions and occurs as discontinuous to semi-continuous lenticular bodies termed 'ore shoots' (Gresham and Loftus-Hills, 1981). The local stratigraphic, metamorphic and structural history at Kambalda closely reflects the regional history in the Kalgoorlie Terrane.

\section{Geodynamic setting of the Kambalda nickel deposits}

Begg et al. (2010) argued that fundamental lithosphere-scale architecture has a major influence on the distribution of magmatichosted Ni deposits and showed that most Ni deposits in the Eastern Goldfields are found along the boundaries of very early developed lithospheric blocks. The Nd model-age map of the Yilgarn Craton (Figure 2) shows the distribution of major Ni and Au deposits in the Eastern Goldfields in relation to the model ages.

The isotopic map can be interpreted as providing a snapshot of the lithospheric architecture at $2650 \mathrm{Ma}$. This map can be considered as a proxy to image major lithospheric discontinuities, which may have acted as active pathways for large volumes of hot, mantle-derived melt to reach upper crustal levels without undergoing any significant differentiation. In other words, steep colour gradients (interpreted as lithosphere-scale boundaries) in Figure 2 show areas where hot magmas were most likely focussed.

Highly mineralised komatiites are most abundant on the western side of the Eastern Goldfields Superterrane, along the boundary between the isotopically juvenile part of the Kalgoorlie Terrane and the older Youanmi Terrane (Figure 2). This boundary may represent a significant lithospheric discontinuity at $2700 \mathrm{Ma}$, along which high volumes of hot komatiites were emplaced and interacted with crustally derived sulfur (cf. Bekker et al., 2009) to generate giant Ni-sulfide ore systems.

\section{Nickel-sulfide mineralisation at Kambalda}

The complete mafic-ultramafic stratigraphy of the Kalgoorlie Terrane is exposed at Kambalda, including the tholeiitic Lunnon Basalt (Figure 4). Nickel mineralisation is hosted in the Silver Lake Member of the Kambalda Komatiite. Thin, sulfidic sedimentary units, comprising dominant pale siliceous sediments, dark, carbonaceous slaty sediments, and minor mafic sediments occur throughout the mafic-ultramafic succession, but are most abundant within the Silver Lake Member of the Kambalda Komatiite (Bavinton, 1981; Gresham and Loftus-Hills, 1981). These sediments may have been a source of sulfur for the mineralisation (e.g., Lesher and Campbell, 1993).

Basal contact mineralisation between the ultramafic flows of the Kambalda Komatiite and the underlying Lunnon Basalt occurs within troughs or channels in the top of the footwall basalts (Lesher, 1983). These troughs or channels have been interpreted as primary features formed through thermal-mechanical erosion by flowing ultramafic lavas that cut down into the sediments overlying the pillowed basalts of the Lunnon Basalt (Lesher, 1983; Beresford et al., 2005). Alternatively, troughs could have formed along pre-existing faults with syn-eruptive graben development (Connors et al., 2002), or during subsequent deformation of the greenstone belt (Stone and Archibald, 2004; Stone et al., 2005). A combination of mechanisms is most likely responsible for the current ore surface configuration.

Troughs in the Kambalda dome area vary in size, but are commonly narrow and elongate with lengths up to 2,300 m and widths $<300 \mathrm{~m}$ (Gresham and Loftus-Hills, 1981). Mineralisation in major troughs is mainly continuous and occurs as small (20-130 m), elliptical orebodies in minor troughs. Stratiform, hanging-wall ore is spatially associated with the basal ore but stratigraphically higher, typically at the contact between first and second flow units and within $100 \mathrm{~m}$ of the komatiite-basalt contact (Gresham and Loftus-Hills, 1981). Some secondary orebodies have been produced by the remobilisation of sulfides into areas of dilation and lower tectonic pressure (e.g., fold hinges, fault dilation zones and shear zones) away from the primary accumulation site (Lesher and Keays, 2002).

The Kambalda Ni deposits illustrate how a series of scaledependent processes, which are reflected in different datasets, have aligned to focus komatiitic magmas and nickel sulfide deposits from the craton to deposit scale.

\section{Gold}

The Eastern Goldfields has produced more than $130 \mathrm{Moz}$ of Au. While there are more than 20 deposits with $>1$ Moz of contained $\mathrm{Au}$ in the region, the Golden Mile at Kalgoorlie is unique in terms of its size and historical production of more than $50 \mathrm{Moz}$ (Western Australia Department of Mines and Petroleum, 2011).

The three recent key advances in the understanding of the distribution of Au mineralisation in the Eastern Goldfields are: 1) the recognition of the influence of large-scale lithospheric architecture on the localisation of mineralisation; 2) the recognition of multiple sources of fluid involved in the deposit genesis, sparking a resurgence of intrusionrelated mineralisation models; and 3) the recognition of multiple timings of mineralisation within single Au deposits or deposit clusters.

Other important advances include the recognition that at least 
some high-temperature deposits have been metamorphosed and the characterisation of large-scale footprints of Au-related hydrothermal alteration that can be potentially be mapped by combinations of spectral and lithogeochemical means.

\section{Large-scale lithospheric architecture}

Blewett et al. (2010b) showed that the distribution of large Au deposits in the Eastern Goldfields is controlled by a favourable convergence of factors from the lithospheric to the deposit scale. A variety of approaches to examining deep-crustal structure, including potential field, magnetotelluric, seismic tomography and reflection seismic data in combination with regional isotopic data have allowed interpretation of deep-crustal-penetrating shear zones which link to structures identified in the upper crust (Blewett et al., 2010b). These fundamental structures, which may act as conduits for fluids, reflect the deep structures identified by Begg et al. (2010) as playing a major role in the distribution of nickel deposits.

\section{Metal sources}

Recent paragenetic and analytical studies have indicated the involvement of three fluids in Au deposits of the Eastern Goldfields (Walshe et al., 2009): 1) a reduced and acid fluid, interpreted to be derived from the upper crust; 2) an oxidised fluid, interpreted as sourced from oxidised magmas; and 3) a reduced fluid, interpreted as sourced from the lower crust or mantle. Despite debate concerning the timing and genesis of the fluids, there is a mounting body of evidence that differing alteration signatures can be detected in regional datasets, including spectral and lithogeochemical data, when normalised to rock type. Recent work indicates that $\mathrm{Au}$ is deposited at gradients in mineralogy and chemistry visible in these datasets and that they provide the potential to map alteration systems and possible sites of deposition (Neumayr et al., 2008).

\section{Timing and structural controls on gold mineralisation}

The distribution of gold mineralisation is structurally controlled, and the timing, style and reactivation of structures are major factors in determining the size of deposits. Blewett et al. (2010a) suggested that $\mathrm{Au}$ was deposited through most of the deformation history but that the major mineralisation took place after the $\mathrm{D}_{3}$ deformation (Figure 5), with Vielreicher et al. (2010) demonstrating, via a variety of techniques, that the main Golden Mile mineralisation at Kalgoorlie took place at c. $2642 \mathrm{Ma}$.

Although the mineralisation event at Kalgoorlie was quite late with respect to the overall structural history of the region, various stages of the structural evolution were responsible for the creation of favourable sites for Au deposition. Weinberg et al. (2004) recognised that deviations on the Boulder-Lefroy shear zone, a major structure common to a number of large deposits in the Kalgoorlie district, provided a first-order focus for the concentration of mineralising fluids in the Kalgoorlie region. These deviations or jogs, which are spaced c. $30 \mathrm{~km}$ apart, were developed during the sinistral transpression stage $\left(\mathrm{D}_{4 \mathrm{~b}}\right.$; Figure 5) of Blewett et al. (2010a), probably at about the same time as the main mineralising event. Going back in time, the extensional event that is associated with granite doming and the development of the late basins $\left(\mathrm{D}_{3}\right.$; Figure 5) played a major role in the creation of sites favourable for Au deposition (Hall, 2007) through the development of suitable fluid pathways (Blewett et al., 2010a).

Going farther back in time, a significant recent advance in understanding $\mathrm{Au}$ mineral systems has been the recognition of the role that the very early structural architecture of greenstone belts plays on the clustering of Au deposits. Studies at St Ives near Kambalda (Figures 2 and 3) have shown that a structural architecture, established at the time of mafic-ultramafic volcanism at c. $2700 \mathrm{Ma}$, has been continually reactivated through c. $70 \mathrm{Myr}$, controlling the subsequent greenstone depositional events, all subsequent responses of the crust to deformation and the location of Au deposits (Miller et al., 2010).

\section{Summary}

The Yilgarn Craton preserves evidence of the oldest crust on Earth, back to c. $4400 \mathrm{Ma}$. The earliest recognisable volcano-sedimentary greenstones were deposited after c. $3000 \mathrm{Ma}$. Isotopic data show that there have been several episodes of crust generation and recycling, the earliest of which are not recognised in the Eastern Goldfields Superterrane. Two major episodes of plume-related magmatism, at c. $2800 \mathrm{Ma}$ and c. $2700 \mathrm{Ma}$, had major consequences for the development and evolution of the craton. The c. 2800 Ma event, the scale of which has only recently been recognised, produced huge mafic-ultramafic igneous complexes in the central part of the craton and was associated with rifting and break-up of the preserved eastern part. The c. 2700 Ma plume, which is responsible for the creation of the world-class nickel deposits of the Eastern Goldfields Superterrane, was focussed between the older cratonic blocks created at the time of the c. 2800 Ma break-up. The arc-like volcano-sedimentary successions in the Kalgoorlie and Kurnalpi terranes of the Eastern Goldfields Superterrane probably formed as result of the re-assembly of the older crustal blocks (Czarnota et al., 2010). Deeply penetrating, extensional structures which developed at this time allowed largescale fluid fluxes and provided loci for the deposition of Au deposits (Blewett et al., 2010a).

Taken together, the advances in understanding craton-scale control on deposit clusters, and emplacement controls on deposit style and mineralisation potential can be used as scale-dependent proxies for exploration (McCuaig et al., 2010). The isotopic datasets can be used as proxies for identifying regions with high potential magma and fluid flux, whereas stratigraphic components such as felsic volcanic and associated sediments, mappable komatiite thickness and presence of assimilated volcanogenic sulfur may mark the position of rifts within these belts, and therefore regions with the highest potential for $\mathrm{Ni}$ sulfide- and VHMS- ore concentrations. Furthermore, these fundamental flaws in the crust appear to control the subsequent response of the crust to deformation and have again focussed fluids during late-cratonic Au mineralisation. An understanding of the local structural architecture and chemically receptive host rocks for hydrothermal mineralisation becomes important at the scale of clusters of deposits and individual deposits.

\section{Acknowledgements}

The authors would like to thank Kevin Cassidy, Jonathon Clarke and John Walshe for helpful reviews. This paper is published with the permission of the Executive Director, Geological Survey of Western Australia. This is contribution 167 from ARC Centre for Excellence for Core to Crust Fluid Systems (http:www.ccfs.mq.edu.au). 


\section{References}

Allibone, A. H., Windh, J., Etheridge, M. A., Burton, D., Anderson, G., Edwards, P. W., Miller, A., Graves, C., Fanning, C. M. and Wysoczanski, R., 1998, Timing relationships and structural controls on the location of $\mathrm{Au}-\mathrm{Cu}$ mineralization at the Boddington Gold Mine, Western Australia: Economic Geology, v. 93, pp. 245-270.

Arndt, N.T. and Jenner, G.A., 1986, Crustally contaminated komatiites and basalts from Kambalda, Western Australia: Chemical Geology, v. 56, pp. 229-255.

Barley, M.E., Brown, S.J.A., Krapez, B. and Kositcin, N., 2008, Physical volcanology and geochemistry of a Late Archean volcanic arc: Kurnalpi and Gindalbie Terranes, Eastern Goldfields Superterrane, Western Australia: Precambrian Research, v. 161, pp. 53-76.

Barnes, S.J., 2004, Introduction to nickel sulphide orebodies and komatiites of the Black Swan area, Yilgarn Craton, Western Australia: Mineralium Deposita, v. 39, pp. 679-683.

Barnes, S.J. (ed), 2006, Nickel deposits of the Yilgarn Craton: geology, geochemistry, and geophysics applied to exploration: Society of Economic Geologists, Special Publication 13, 210 pp.

Barnes, S.J., Lesher, C.M. and Sproule, R.A., 2007, Geochemistry of komatiites in the Eastern Goldfields Superterrane, Western Australia and the Abitibi Greenstone Belt, Canada, and implications for the distribution of associated Ni-Cu-PGE deposits: Transactions of the Institute of Mining and Metallurgy, Series B (Applied Earth Science), v. 116, pp. 167-187.

Bavinton, O.A., 1981, The nature of sulfidic metasediments at Kambalda and their broad relationships with associated ultramafic rocks and nickel ore: Economic Geology, v. 78, pp. 1606-1628.

Bekker, A., Barley, M.E., Fiorentini, M., Rouxel O.J., Rumble D. and Beresford, S.W., 2009, Atmospheric sulfur in Archaean komatiite-hosted nickel deposits: Science, v. 326, pp. 1086-1089.

Begg, G.C., Hronsky, J.A.M., Arndt, N.T., Griffin, W.L., O'Reilly, S.Y. and Hayward, N., 2010, Lithospheric, cratonic, and geodynamic setting of Ni-Cu-PGE sulfide deposits: Economic Geology, v. 105, pp. 1057-1070.

Beresford, S., Stone, W.E., Cas, R., Lahaye, Y. and Jane, M., 2005, Volcanological controls on the localization of the komatiite-hosted Ni$\mathrm{Cu}$-(PGE) Coronet Deposit, Kambalda, Western Australia: Economic Geology, v. 100, pp. 1457-1467.

Blewett, R.S., Czarnota, K., Henson, P.A., Champion, D.C., 2010a, Structuralevent framework for the eastern Yilgarn Craton, Western Australia, and its implications for orogenic gold: Precambrian Research, v. 183, pp. 203-229.

Blewett, R.S., Henson, P.A., Roy, I.G., Champion, D.C. and Cassidy, K.F., 2010b, Scale-integrated architecture of a world-class gold mineral system: The Archaean eastern Yilgarn Craton, Western Australia: Precambrian Research, v. 183, pp. 230-250.

Campbell, I.H. and Hill, R.I., 1988, A two-stage model for the formation of the granite-greenstone terrains of the Kalgoorlie-Norseman area, Western Australia: Earth and Planetary Science Letters, v. 90, pp. 11-25.

Cassidy, K.F., Champion, D.C., McNaughton, N.J., Fletcher, I.R., Whitaker, A.J., Bastrakova, I.V. and Budd, A.R., 2002, Characterisation and metallogenic significance of Archaean granitoids of the Yilgarn Craton, Western Australia: Minerals and Energy Research Institute of Western Australia (MERIWA), Report No. 222, 514 pp.

Cassidy, K.F., Champion, D.C., Krapez, B., Barley, M.E., Brown, S.J.A., Blewett, R.S., Groenewald, P.B. and Tyler, I.M., 2006, A revised geological framework for the Yilgarn Craton, Western Australia: Geological Survey of Western Australia, Record 2006/8, 8 pp.

Champion, D.C. and Cassidy, K.F., 2007, An overview of the Yilgarn Craton and its evolution, in Bierlein, F.P. and Knox-Robinson, C.M. (eds), Proceedings of Geoconferences (WA) Inc. Kalgoorlie 07 Conference, 2527 September 2007: Geoscience Australia, Record 2007/14, pp. 8-13.

Compston, W., Williams, I.S., Campbell, I.H. and Gresham, J.J., 1986, Zircon xenocrysts from the Kambalda volcanics: age constraints and direct evidence for older continental crust below the Kambalda-Norseman greenstones: Earth and Planetary Science Letters, v. 76, pp. 299-311.

Connors, K.A., Stolz, E.M.G. and Hanneson, J.E., 2002, Early fault architecture at St Ives: implications for Au and Ni mineralisation, in Vearncombe, S. (ed), Applied Structural Geology for Mineral Exploration and Mining: Australian Institute of Geoscientists, Bulletin, v. 36, pp. 29-31.
Czarnota, K., Champion, D.C., Cassidy, K.F., Goscombe, B., Blewett, R.S., Henson, P.A., Groenewald, P.B., 2010, Geodynamics of the Eastern Goldfields Superterrane: Precambrian Research, v. 183, pp. 175-202.

Dentith, M., Evans, S., Thiel, S., Gallardo, L., Joly, A. and Romano, S.S., 2012, A magnetotelluric traverse across the southern Yilgarn Craton: Geological Survey of Western Australia, Report (in press).

Drummond, B.J., Goleby, B.R. and Swager, C.P., 2000, Crustal signature of Late Archaean tectonic episodes in the Yilgarn Craton, Western Australia: evidence from deep seismic sounding: Tectonophysics v. 329, pp. 193221.

Fiorentini, M.L., Barley, M.E., Pickard, A., Beresford, S.W., Rosengren, N., Cas, R. and Duuring, P., 2005, Age constraints of the structural and stratigraphic architecture of the Agnew-Wiluna greenstone belt: implications for the age of komatiite-felsic association and interaction in the Eastern Goldfields Province, Western Australia. Minerals and Energy Research Institute of Western Australia (MERIWA), Report No. 255, $39 \mathrm{pp}$.

Fiorentini, M.L., Rosengren, N., Beresford, S.W., Grguric, B. and Barley, M.E., 2007, Controls on the emplacement and genesis of the MKD5 and Sarah's Find Ni-Cu-PGE deposits, Mount Keith, Agnew-Wiluna Greenstone Belt, Western Australia: Mineralium Deposita, v. 126, pp. 847-877.

Fiorentini, M.L., Beresford, S.W., Rosengren, N., Barley, M.E. and McCuaig, T.C., 2010, Contrasting komatiite belts, associated Ni-Cu-(PGE) deposit styles and assimilation histories: Australian Journal of Earth Sciences, v. 57 , pp. $543-566$.

Geological Survey of Western Australia, 2011, Geochronology: <http:// www.dmp.wa.gov.au/geochron>

Goleby, B.R., Blewett, R.S., Groenewald, P.B., Cassidy, K.F., Champion, D.C., Jones, L.E.A., Korsch, R.J., Shevchenko, S., Apak, S.N., 2003, The 2001 northeastern Yilgarn deep seismic reflection survey: Geoscience Australia, Record 2003/28, 143 pp.

Goscombe, B., Blewett, R.S., Czarnota, K., Groenewald, B., Maas, R., 2009. Metamorphic evolution and integrated terrane analysis of the eastern Yilgarn Craton: Rationale, methods, outcomes and interpretation: Geoscience Australia, Record 2009/23, 270 pp.

Gresham, J. J. and Loftus-Hills, G. D., 1981, The geology of the Kambalda nickel field, Western Australia: Economic Geology, v. 76, pp. 1373-1416.

Hall, G., 2007, Exploration success in the Yilgarn Craton insights from the Placer Dome experience the need for integrated research, in Bierlein, F.P. and Knox-Robinson, C.M. (eds), Proceedings of Geoconferences (WA) Inc. Kalgoorlie 07 Conference, 25-27 September 2007: Geoscience Australia, Record 2007/14, pp. 199-202.

Hill, R.E.T., Barnes, S.J., Gole, M.J. and Dowling, S.J., 1995, The volcanology of komatiites as deduced from field relationships in the Norseman-Wiluna greenstone belt, Western Australia: Lithos, v. 34, pp. 159-188.

Huston, D.L., Champion, D.C. and Cassidy, K.F., 2005, Tectonic controls on the endowment of Archean cratons in VHMS deposits: evidence from $\mathrm{Pb}$ and $\mathrm{Nd}$ isotopes, in Mao, J. and Bierlein, F.P. (eds), Proceeding of the Eighth Biennial SGA Meeting, Beijing, China, 18-21 August 2005: Springer, pp. 15-18.

Ivanic, T.J., Wingate, M.T.D., Kirkland, C.L., Van Kranendonk, M.J. and Wyche, S., 2010, Age and significance of voluminous mafic-ultramafic magmatic events in the Murchison Domain, Yilgarn Craton: Australian Journal of Earth Sciences, v. 57, pp. 597-614

Kinny, P.D., Williams, I.S., Froude, D.O., Ireland, T.R. and Compston, W., 1988, Early Archaean zircon ages from orthogneisses and anorthosites at Mount Narryer, Western Australia: Precambrian Research, v. 38, pp. 325-341.

Kositcin, N., Brown, S.J.A., Barley, M.E., Krapez, B., Cassidy, K.F. and Champion, D.C., 2008, SHRIMP U-Pb zircon age constraints on the Late Archaean tectonostratigraphic architecture of the Eastern Goldfields Superterrane, Yilgarn Craton, Western Australia: Precambrian Research, v. 161 , pp. $5-33$

Krapez, B. and Barley, M.E., 2008, Late Archaean synorogenic basins of the Eastern Goldfields Superterrane, Yilgarn Craton, Western Australia. Part III: Signatures of tectonic escape in an arc-continent collision zone: Precambrian Research, v. 161, pp.183-199.

Krapez, B. and Hand, J.L., 2008, Late Archaean deep-marine volcaniclastic sedimentation in an arc-related basin: the Kalgoorlie Sequence of the Eastern Goldfields Superterrane, Yilgarn Craton, Western Australia: Precambrian Research, v. 161, pp. 89-113. 
Krapez, B., Barley, M.E. and Brown, S.J.A., 2008, Late Archaean synorogenic basins of the Eastern Goldfields Superterrane, Yilgarn Craton, Western Australia Part I. Kalgoorlie and Gindalbie Terranes: Precambrian Research, v. 161, pp. 135-153.

Lesher, C.M. 1983, Localization and genesis of komatiite-associated Fe-Ni$\mathrm{Cu}$ sulphide mineralization at Kambalda, Western Australia: PhD thesis, The University of Western Australia, Perth, Western Australia, 199 pp. (unpublished)

Lesher, C.M. and Campbell, I.H., 1993, Geochemical and fluid dynamic modeling of compositional variations in Archean komatiite-hosted nickel sulfide ores in Western Australia: Economic Geology, v. 88, pp. 804816.

Lesher, C.M. and Keays, R.R., 2002, Komatiite-associated Ni-Cu-PGE deposits: geology, mineralogy, geochemistry, and genesis, in Cabri, L.J. (ed), The Geology, Geochemistry, Mineralogy, and Mineral Beneficiation of Platinum-Group Elements: Canadian Institute of Mining, Metallurgy and Petroleum, Special Volume 54, pp. 579-618.

McCuaig, T.C., Beresford, S. and Hronsky, J., 2010 translating the mineral systems approach into an effective exploration targeting system: Ore Geology Reviews, v. 38, pp. 128-138.

Miller, J., Blewett, R., Tunjic, J. and Connors, K., 2010, The role of early formed structures on the development of the world class St Ives Goldfield, Yilgarn, WA: Precambrian Research, v. 183, pp. 292-315.

Mole, D.R., Fiorentini, M., Thebaud, N., McCuaig, C., Cassidy, K.F., Barnes, S.J., Belousova, E. A., Mudrovska, I. and Doublier, M., 2010, Lithospheric controls on the localization of komatiite-hosted nickel-sulfide deposits, in Tyler I. M. and Knox-Robinson C. M. (eds), Fifth International Archean Symposium Abstracts: Geological Survey of Western Australia, Record 2010/18, pp. 101-103.

Neumayr, P., Walshe, J., Hagemann, S., Petersen, K., Roache, A., Frikken, P., Horn, L. and Halley, S., 2008, Oxidized and reduced mineral assemblages in greenstone belt rocks of the St. Ives gold camp, Western Australia: vectors to high-grade ore bodies in Archaean gold deposits? Mineralium Deposita, v. 43, pp. 363-371.

Pawley, M.J., Wingate, M.T.D., Kirkland, C.L., Wyche, S., Hall, C.E., Romano, S.S. and Doublier, M.P., 2012, Adding pieces to the puzzle: episodic crustal growth and a new terrane in the northeast Yilgarn Craton, Western Australia: Australian Journal of Earth Sciences (in press).

Rasmussen, B., Fletcher, I.R., Muhling, J.R. and Wilde, S.A., 2010, In situ $\mathrm{U}-\mathrm{Th}-\mathrm{Pb}$ geochronology of monazite and xenotime from the Jack Hills belt: Implications for the age of deposition and metamorphism of Hadean zircons: Precambrian Research, v. 180, pp. 26-46.

Reading, A.M., Kennett, B.L.N. and Goleby, B., 2007, New constraints on the seismic structure of West Australia: evidence for terrane stabilization prior to assembly of an ancient continent: Geology, v. 35, pp. 379-382.

Rosengren, N.M., Cas, R.A.F., Beresford, S.W. and Palich, B.M., 2005, Reconstruction of an extensive Archaean dacitic submarine volcanic complex associated with the komatiite-hosted Mt Keith nickel deposit, Agnew-Wiluna Greenstone Belt, Yilgarn Craton, Western Australia: Precambrian Research, v. 161, pp. 34-52.

Said, N. and Kerrich, R., 2009, Geochemistry of coexisting depleted and enriched Paringa Basalts, in the 2.7 Ga Kalgoorlie Terrane, Yilgarn Craton, Western Australia: Evidence for a heterogeneous mantle plume event: Precambrian Research, v. 174, pp. 287-309.

Smithies, R.H. and Champion, D.C., 1999, Late Archaean felsic alkaline igneous rocks in the Eastern Goldfields, Yilgarn Craton, Western Australia: a result of lower crustal delamination? Journal of the Geological Society, London, v. 156, pp. 561-576.

Squire, R.J., Cas, R.A.F., Clout, J.M.F. and Behets, R., 1998, Volcanology of the Lunnon Basalt and its relevance to nickel sulfide-bearing trough structures at Kambalda, Western Australia: Australian Journal of Earth Sciences, v. 45, pp. 695-715.

Squire, R.J., Allen, C.M., Cas, R.A.F., Campbell, I.H., Blewett, R.S., Enchain,
A.A., 2010, Two cycles of voluminous pyroclastic volcanism and sedimentation related to episodic granite emplacement during the late Archean: Eastern Yilgarn Craton, Western Australia: Precambrian Research, v. 183, pp. 251-274.

Stone, W.E. and Archibald, N.J., 2004, Structural controls on nickel sulfide ore shoots in Archean komatiite, Kambalda, WA: the volcanic trough controversy revisited: Journal of Structural Geology, v. 26, pp. 11731194.

Stone, W.E., Beresford, S.W. and Archibald, N.J., 2005, Structural setting and shape analysis of nickel sulphide shoots at the Kambalda Dome, Western Australia: implications for deformation and remobilization: Economic Geology, v. 100, pp. 1441-1455.

Swager, C.P., 1997, Tectono-stratigraphy of late Archaean greenstone terranes in the southern Eastern Goldfields, Western Australia: Precambrian Research, v. 83, pp. 11-42.

Swager, C.P., Griffin, T.J., Witt, W.K., Wyche, S., Ahmat, A.L., Hunter, W.M. and McGoldrick, P.J., 1995, Geology of the Archaean Kalgoorlie Terrane - an explanatory note: Geological Survey of Western Australia, Report 48, $26 \mathrm{pp}$.

Swager, C.P., Goleby, B.R., Drummond, B.J., Rattenbury, M.S. and Williams, P.R., 1997, Crustal structure of granite-greenstone terranes in the Eastern Goldfields, Yilgarn Craton, as revealed by seismic profiling: Precambrian Research, v. 83, pp. 43-56.

Trofimovs, J., Davis, B.K. and Cas, R.A.F., 2004, Contemporaneous ultramafic and felsic intrusive and extrusive magmatism in the Archaean Boorara Domain, Eastern Goldfields Superterrane, Western Australia, and its implications: Precambrian Research, v. 131, pp. 283-304.

Van Kranendonk, M.J., Ivanic, T.J., Wingate, M.T.D., Kirkland, C.L. and Wyche, S., 2012, Long-lived, autochthonous development of the Archean Murchison Domain, Yilgarn Craton: Precambrian Research (in press).

Vielreicher, N.M., Groves, D.I., Snee, L.W., Fletcher, I.R. and McNaughton, N.J., 2010, Broad synchroneity of three gold mineralization styles in the Kalgoorlie gold field: SHRIMP, U-Pb, and ${ }^{40} \mathrm{Ar} r^{39} \mathrm{Ar}$ geochronological evidence: Economic Geology, v. 105, pp. 187-227.

Walshe, J.L., Neumayr, P., Cleverley, J., Petersen, K., Andrew, A., Whitford, D., Carr, G.R., Kendrick, M., Young, C. and Halley, S., 2009, Question 3: Multiple fluid reservoirs in Eastern Yilgarn gold systems, in Concepts to Targets: a scale-integrated mineral systems study of the Eastern Yilgarn Craton: pmd*CRC, Project Y4, Final Report, Part III, pp. 113-152.

Wang, Q., Schiøtte, L. and Campbell, I.H., 1998, Geochronology of supracrustal rocks from the Golden Grove area, Murchison Province, Yilgarn Craton, Western Australia: Australian Journal of Earth Sciences, v. 45 , p. $571-577$.

Weinberg, R.F., Hodkiewicz, P.H. and Groves, D.I., 2004, What controls gold distribution in Archean terranes? Geology, v. 32, pp. 545-548.

Western Australia Department of Mines and Petroleum, 2011, Resources data files: http://www.dmp.wa.gov.au/1521.aspx.

Wilde, S.A., Valley, J.W., Peck, W.H. and Graham, C.M., 2001, Evidence from detrital zircons for the existence of continental crust and oceans on Earth 4.4 Gyr ago: Nature, v. 409, pp. 175-178.

Woodall, R., 1965, Structure of the Kalgoorlie goldfield, in McAndrew, J. (ed), Geology of Australian Ore Deposits (2nd edition), $8^{\text {th }}$ Commonwealth Mining and Metallurgical Congress, Australia and New Zealand: Australian Institute of Mining and Metallurgy, v. 1, pp. 71-79.

Wyche, S., Kirkland, C.L., Riganti, A., Pawley, M.J., Belousova, E. and Wingate, M.T.D., 2012, Isotopic constraints on stratigraphy in the central and eastern Yilgarn Craton, Western Australia: Australian Journal of Earth Sciences (in press).

Yeats, C. J., McNaughton, N. J. and Groves, D. I.,1996, SHRIMP U-Pb geochronological constraints on Archean volcanic-hosted massive sulfide and lode gold mineralization at Mount Gibson, Yilgarn Craton, Western Australia: Economic Geology, v. 91, pp. 1354-1371. 


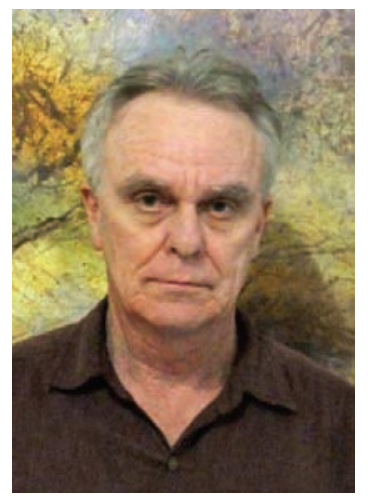

Stephen Wyche is the Manager of Yilgarn Craton mapping projects at the Geological Survey of Western Australia. He has over 30 years of experience of mapping in Proterozoic and Archean terrains in Australia, including more than 20 years in the Yilgarn Craton. He has been involved in geological mapping and research programs over most of the Yilgarn Craton and has published papers on various aspects of its stratigraphy, structure and tectonic history.

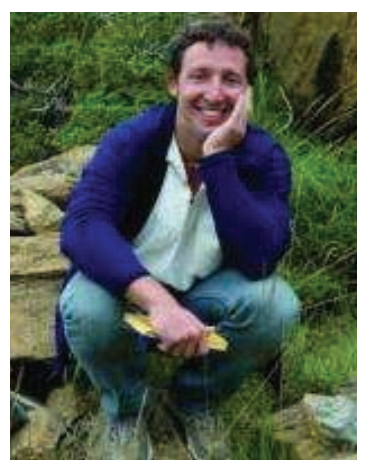

Marco Fiorentini is a Research Associate Professor at the Centre for Exploration Targeting at the University of Western Australia. His main research involves nickel mineral system analysis and development of PGEbased exploration tools for $\mathrm{Ni}-\mathrm{Cu}-$ $P G E$ mineralisation associated with mafic and ultramafic systems. He is also interested in the early Earth, the geochemistry of PGEs, the role of volatiles in the petrogenesis of Precambrian mafic and ultramafic systems..

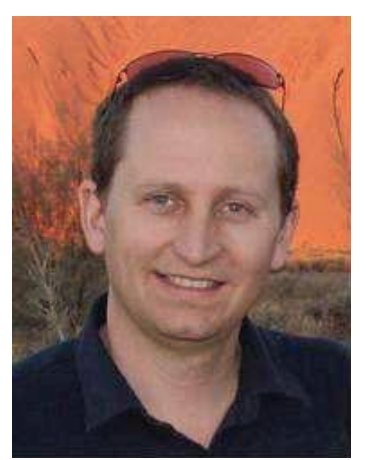

John Miller is a Research Professor at the Centre for Exploration Targeting at the University of Western Australia. He is a structural specialist in mineral deposits whose principal research interests are structural controls on gold mineralisation, Ar/Ar geochronology and tectonics.

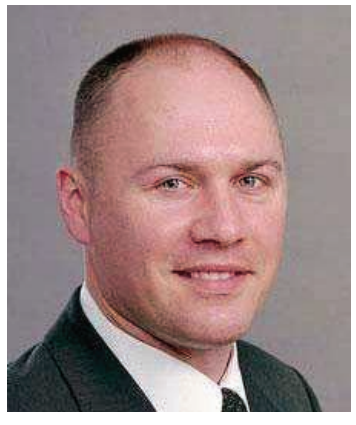

Professor Cam McCuaig received his BSc from Lakehead University in 1988, and PhD in Geology from the University of Saskatchewan in 1996. His experience spans 6 continents and numerous commodities (including $\mathrm{Au}, \mathrm{Ni}, \mathrm{Fe}, \mathrm{Cu}, \mathrm{U}$ and $\mathrm{Zn}$ ) in geological terranes ranging from Archean to Eocene in age. For the past 6 years, Cam has been Director of the Centre for Exploration Targeting, a joint venture between the University of Western Australia, Curtin University, and the Minerals Industry that is focussed on advancing the science of exploration targeting. 